\title{
Thorium Th 227 Anetumab
}

National Cancer Institute

\section{Source}

National Cancer Institute. Thorium Th 227 Anetumab. NCI Thesaurus. Code C155977.

A radioimmunoconjug ate consisting of anetumab, a human immunog lobulin G1 (IgG1)

monoclonal antibody directed against the cell surface glycoprotein mesothelin,

conjug ated to an as of yet not disclosed chelating agent, and labeled with the alpha-

emitting radioisotope thorium Th 227, with potential antineoplastic activity. Upon

administration the monoclonal antibody moiety of thorium Th 227 anetumab binds to

the tumor-associated antigen (TAA) mesothelin, delivering a cytotoxic dose of alpha

radiation to cells expressing mesothelin. 